シの易動性が增加して，イオン配列の乱れが減少する万向にむか い，活性が减少する。雾团気による影響については, アンモニ〉 ガス中や水蒸気中の低温力焼の場合， $Q_{\mathrm{B}}$ が大きいのは表面層に おける化合物の生成分解によって，表面イオンの配列が乱れてい るものと考えられる。高温になると一般にイオンの易動性が増す ので, 表面は安定化するのであるが，これらの気体の存在が真空 中ないし乾燥空気中に比べてょり安定な表面を形成するよ5に作
用しているすのと考えられる。な打 $\mathrm{NH}_{3}$ は分解して $\mathrm{H}_{2}$ を出す であろう。水素が存在すると $1500^{\circ} \mathrm{C}$ 以上では $\mathrm{MgO}$ 結晶の昇華 が促進されることが知られている9。本実験の温度ではすちろん 昇華は考えられないが，Mg0 表面に作用してより安定な配列に 移るための易動性に寄与することは考劣られるであろう。

9) L. Navias, J. Am. Ceram. Soc. 44, 434 (1961).

\title{
テビトロセラミックスの化学的耐久性に関する研究 酸に対する溶解現象
}

(昭 和 38 年 1 月 22 日受理)

\author{
森 谷 太 郎・境 野 照 雄・滝 沢 一 貴*
}

特殊な組成をもつガラスはある温度範囲で適当な熱処理をおこな5と一様に結晶化して, むとのガラスと異なった性質 の結晶組織をるつ物質ができる。このように最初がラスを作って後で適当な熱処理によって，すとのガラスよりも優れた 性質をるつ結晶化した新しい工業材料を著者らは“デビトロセラミックス” (Devitroceramics) と呼んでいる。

本研究は，デビトロセラミックスの化学的耐久性に対する一つの目安として，酸に対する溶解現象を明らかにすること を目的として行なわれた。

$\mathrm{Li}_{2} \mathrm{O} \cdot \mathrm{Al}_{2} \mathrm{O}_{3} \cdot 3 \mathrm{SiO}_{2}$ ガラスおよびマイカ・スポシューメン系ガラスならびにそれらの結晶化物のフッ化水素酸および硫 酸に対する溶解速度について, 温度および濃度変化によってどのように影響されるかを実験した。また硫酸に対する溶解 式をガラス扰よびデビトロセラミックスについてそれぞれ求めた。

\section{1 粕言}

一般ガラスの化学的耐久性に対しては従来から多くの研究が行 なわれてきた，すなわち水に対する耐水性 ${ }^{1,2)}$ ，酸扣よびアルカ リに対する耐久性について，ガラスの化学組成，熱処理等によっ てどのように影響されるか, というような研究が数多く発表され きた。

デビトロセラミックスは最初アメリカのコーニングガラス会社 の Stookey 博士によって研究され，パイロセラムとい5商品名 によって公表されだ)。また Stookey は $\mathrm{Li}_{2} \mathrm{O}-\mathrm{Al}_{2} \mathrm{O}_{3}-\mathrm{SiO}_{2}$ 系ガ ラスを基体とし，これに金銀銅等を少量添加し，さらに還元剤と して酸化セリウムを加えたものに，紫外線を照射して後に熱処理 すれば，金銀銅等がガラス中でコロイド状となり，これが結晶核 となって結晶がその場所に析出することを発見し，これを感光性 ガラスと名付けた4。

著者らはデビトロセラミックスの化学組成, 結晶化過程, 基礎 的性質等について研究してきた ${ }^{5 \sim 7)}$ 。

本研究に批いては， $\mathrm{Li}_{2} \mathrm{O} \cdot \mathrm{Al}_{2} \mathrm{O}_{3} \cdot 3 \mathrm{SiO}_{2}$ ガラス拈よびマイカ・ スポジューメン系ガラスについて，そのガラス状態と結晶状態と について, 特にフッ化水素酸および硫酸に対する溶解過程を研究

* 東京工業大学 : 東京都目黒区大岡山.

1) 森谷, 工化 43,884 (1940).

2) R. W. Douglass, J. Soc. Glass Techn. 33, 289 (1949).

3) S. D. Stookey, Ind. Eng. Chem. 45, 115 (1953).

4) S. D. Stookey, ibid. 41, 856 (1949).

5）森谷, 境野, 才野, 遠藤, 堂協, 68, 44 (1960).

6) 森谷, 境野, 田中, 工化 63, 1129 (1960).

7) 林谷, 境野, 才野, 滝沢, 案協 68, 103 (1960).
し, 両状態の場合について溶解温度吅よび酸の濃度等の溶解速度 に及ぼす影響について報告する。

\section{2 実験および実験結果}

\section{$2 \cdot 1$ 実験試料の調製}

実験に供した試料の化学組成は 2 種類で，その一つは 3 成分系 で,

(a) $\mathrm{Li}_{2} \mathrm{O} \cdot \mathrm{Al}_{2} \mathrm{O}_{3} \cdot 3 \mathrm{SiO}_{2}$ (以下これを $\mathrm{LAS}_{3}$ と呼ぶ)

他は実用的組成のものとして,

(b) $\left\{\begin{array}{l}\text { スポシューメン }\left(\mathrm{Li}_{2} \mathrm{O} \cdot \mathrm{Al}_{2} \mathrm{O}_{3} \cdot 4 \mathrm{SiO}_{2}\right) 35 \mathrm{~mol} \% \\ \text { 金雲母 }\left(\mathrm{Li}_{1 / 3}, \mathrm{Na}_{2 / 3}, \mathrm{Mg}_{3}\left(\mathrm{Si}_{3} \mathrm{AlO}_{10}\right) \mathrm{F}_{2}\right) 45 \mathrm{~mol} \% \\ \text { フルミニウム・シリケート }\left(\mathrm{Al}_{2} \mathrm{O}_{3} \cdot \mathrm{SiO}_{2}\right) 20 \mathrm{~mol} \%\end{array}\right.$

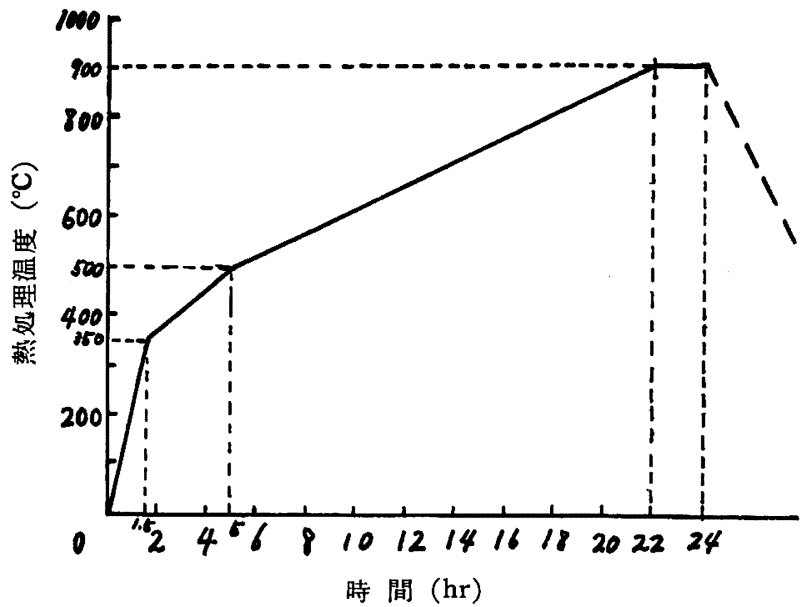

图 1 熱処理曲線 
なる混合組成のものに，融剂として， $3 \mathrm{~mol} \%$ の $\mathrm{B}_{2} \mathrm{O}_{3}$ を添加し たものを選んた（以下これをMS 系試料と呼ら゙)。

ガラスバッチの調製は一般のガラスと同じ方法で調製し，その $10 \mathrm{~kg}$ を高アルミナ質ルッボて， $1400 〜 1500^{\circ} \mathrm{C}$ で約 2 時間溶融 したのち，棒状試料並びに粉末試料を作製した。溶解に用いた粉 末は，14〜20 メッシュで節別し，アルコールで洗浄し， $115^{\circ} \mathrm{C}$ で譤燥した。この粉末陚料の一部を, 図1に示温度スケジュー ルにしたがって熱処理を行なってガラスを絬晶化し，デビトロセ ラミックス陚料とした(以下結晶化試料と呼ぶ)。このような結品 化試料はいずれる乳白色不透明である。

$\mathrm{X}$ 線分析火よって結晶化試料中火生成している結晶は, $\mathrm{LAS}_{3}$ 試料に沏いては， $\beta$-スポジューメンであり，MS 系試料沶いて は, マイカと $\beta$ スポジューメンであった。

\section{$2 \cdot 27 ッ$ 化水素酸に対する溶解実験}

浴解実験は次の手順でおこなった。すなわち，先ず，粉末試料 $1.00 \mathrm{~g}$ を值経 $2 \mathrm{~cm}$, 高さ $3 \mathrm{~cm}$ の円简形の白金網籠中に入れ, これを一定温度の $47 \mathrm{wt} \%$ のフッ化水素酸の $1 / 50$ 希釈液に溶 解したのち取出し, 蒸留水中で籠を振動しながら水洗し, 陚料表 面に生成した反応生成物を除き, 乾燥してから試料の重量减少量 を测定して, 試料 $1 \mathrm{~g}$ 当りの重量减少量を求めて, これを溶解 率 $\alpha$ とした。溶解率 $\alpha$ と溶解時間との関保を点緅し溶解曲線 を描いた。溶解笑験に用いた装圆の略図を図 2 に示した。

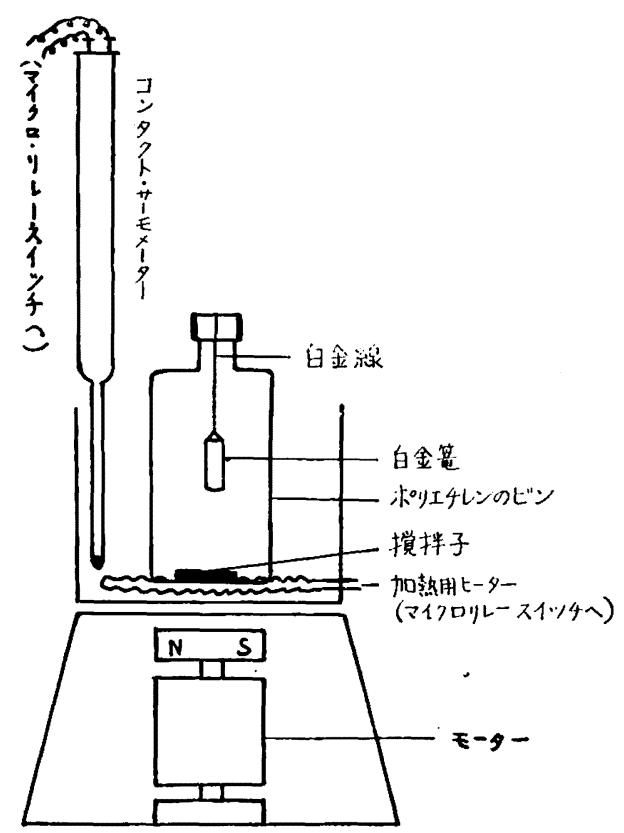

図 2 溶解装置図

2.2.1 カラスの溶解実験 $\mathrm{LAS}_{3}$ 陚料のガラスに対する溶解 曲線は四 3-a k示すよ5になる。この場合の溶解温度は $42.3^{\circ} \mathrm{C}$ であり, 最初 7 分間フッ化水素酸に浴解したのち前述の方法で蒸 留水または適当な硫酸浴夜で試料表面の生成付着物を洗い落とし てから，試料の重量を测定してその溶解率を求め、次に再び第 2 回目の 7 分間の溶解を行ない, 前回同様洗浄して秤量し, 第 3 回 目の溶解を行なら。これを絽返し行なったものを点緅したもので ある。また MS 系ガラス陚料に対する曲線を図 3-b 亿示した。 四からわかるよ 料も同一形状を示すか，MS 系の方が $\mathrm{LAS}_{3}$ よりも溶解速度は

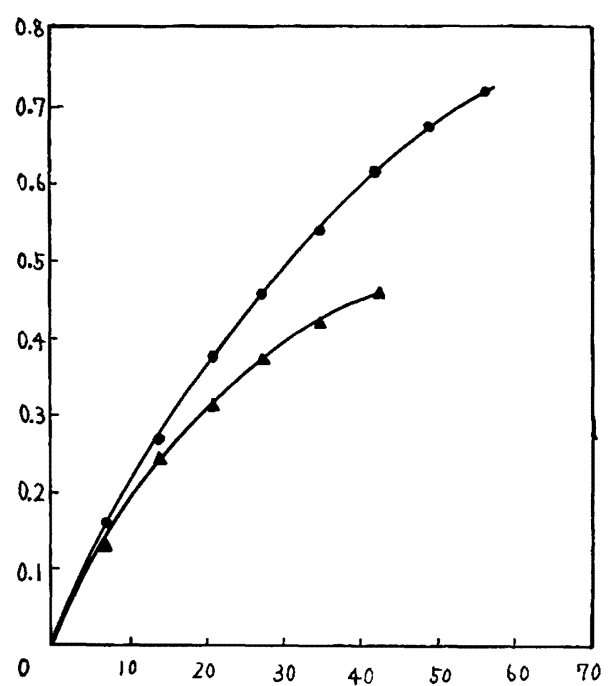

図 $3 \mathrm{LAS}_{3}$ 扰上びマイカースボジューメン系 ガラス試料の溶解曲線

○ : a $\quad$ : b

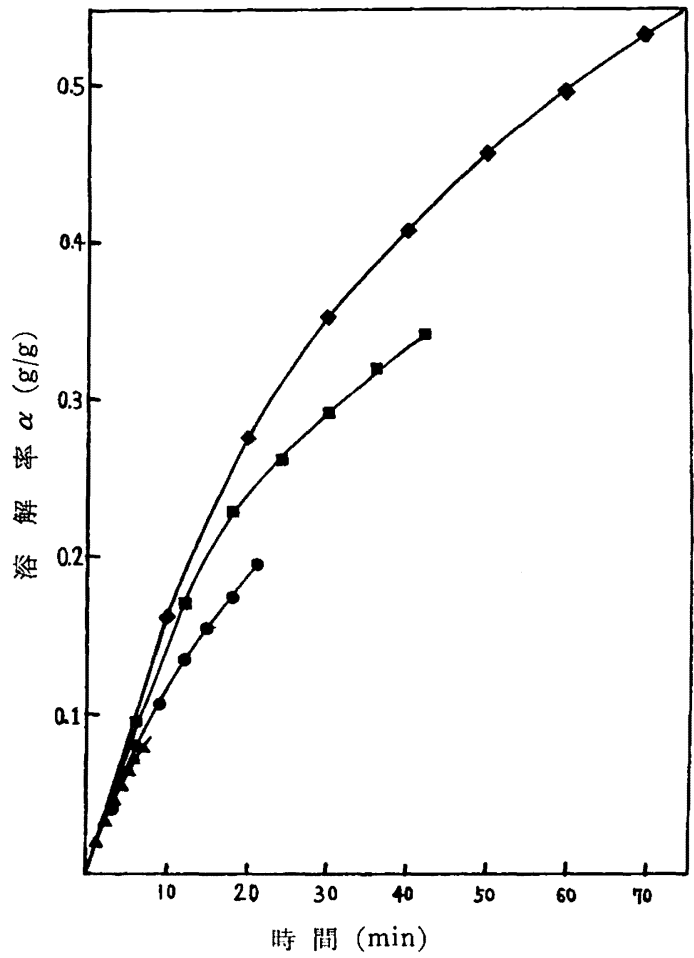

図 4 マイカースポシューメン系ガラス試料の浴解曲線

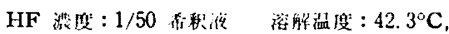
沈洋被: $0.5 \mathrm{~N} \mathrm{H}_{2} \mathrm{SO}_{4}$ 沈洋㭙間: $5 \mathrm{~min}$

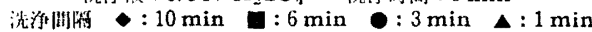

小さいことがわかる。また図4はMS 系試料について洗浔間隔 （フッ化水素酸に対する 1 回の溶解規定時間）をそれぞれ 1 分， 3 分， 6 分，10 分とし，洗浄時間を每回いずれも5 分間とした。 洗海液には $0.5 \mathrm{~N}$ の硫酸を用いた。

\section{$2 \cdot 2 \cdot 2$ 結晶化物の溶解実験}

ガラス粉末を前述国1のような熱処理スケジュールに従って結 晶化し，それを前述と同一の装置を用いて溶解实験を行なった。 $\mathrm{LAS}_{3}$ 結晶化物の溶解曲線を図 5 に示した。この場合洗浄は蒸留 水にて行ない， 1 回の溶解規定眝間を 7 分とした。溶解曲線は渂 
初は直線的に上昇し，時間の経過と共に溶解速度が減少する様子 を示した。

また MS 系試料の結晶化物の溶解曲線を図6 6 亿示した。この

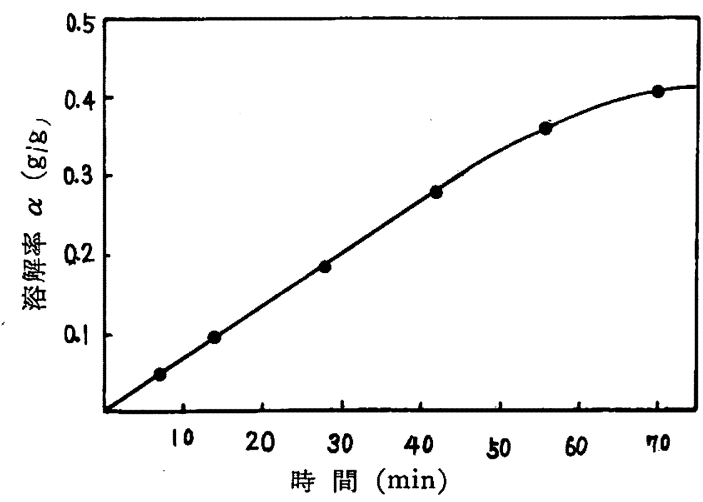

図 $5 \mathrm{LAS}_{3}$ 系結晶化試料の溶解曲線

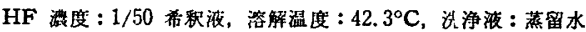

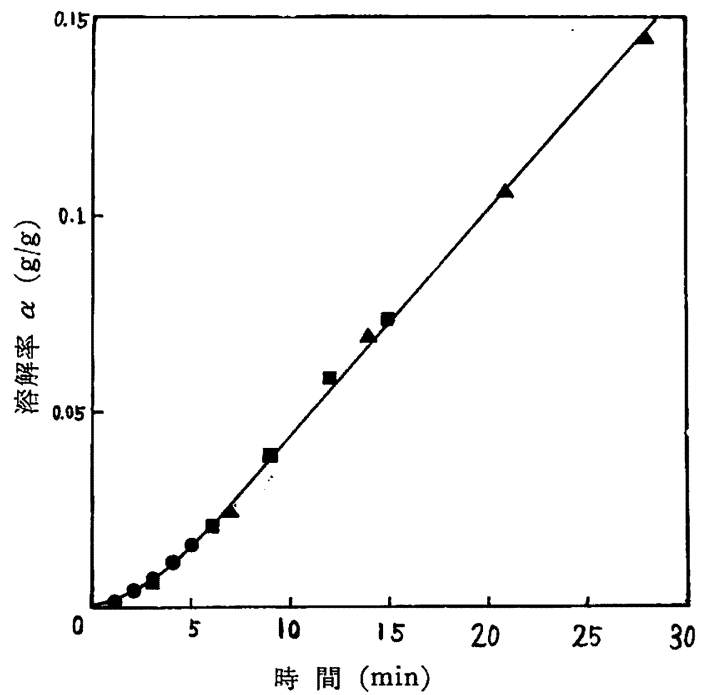

因 6 マイカースポシューメン系結晶化試料の溶解曲線

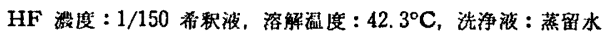

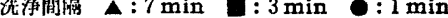

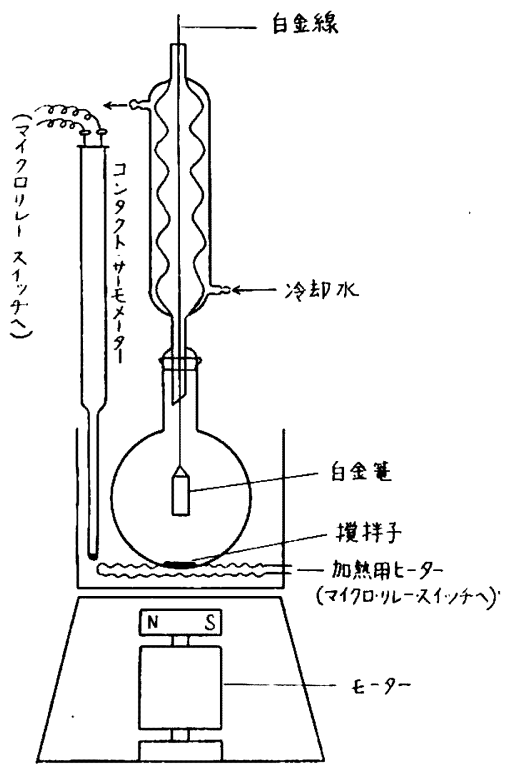

図 7 溶解装置図
場合 フッ化水素の 濃度は $1 / 150$ 希釈液を用いた。

また洗浄間隔をそれぞれ 1 分, 3 分, 7 分と变化し た場合について示した。フ ッ化水素酸の濃度が同じで あれば, 洗浄間隔を变化さ せても，溶解曲線は变わら ない。

また溶解速度は時間の最 初は時間とともに増すが, ある時間の後は一定速度を 示すことがわかる。

\section{$2 \cdot 3$ 硫酸に対する溶解 実験}

フッ化水素酸に対する実 験と同様に試料粉末を白金 網籠中に入れ，図 7 に示す 装置を用いて実験した。硫

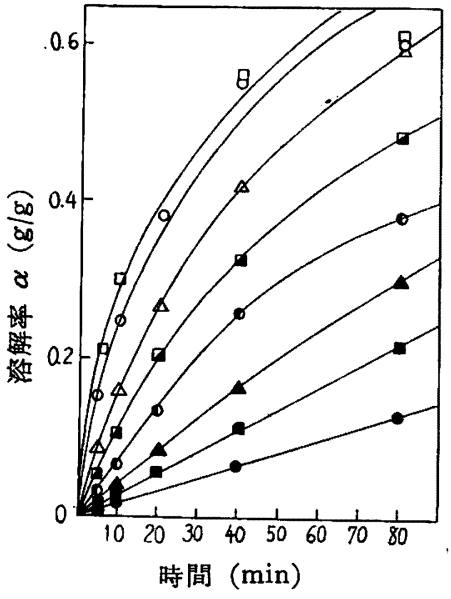

図 8 溶解温度を変化した場合の $\mathrm{LAS}_{3}$ ガラス試料の溶解曲線 $\mathrm{H}_{2} \mathrm{SO}_{4}$ 灌度 $: 0.5 \mathrm{~N}$

: 溶解榅度

$\square: 89^{\circ} \mathrm{C} \quad 0: 84^{\circ} \mathrm{C} \quad \triangle: 75^{\circ} \mathrm{C}$ : $68.5^{\circ} \mathrm{C} \quad 0: 62.5^{\circ} \mathrm{C} \triangle: 55^{\circ} \mathrm{C}$ $: 47.7^{\circ} \mathrm{C} \quad: \quad 40.2^{\circ} \mathrm{C}$

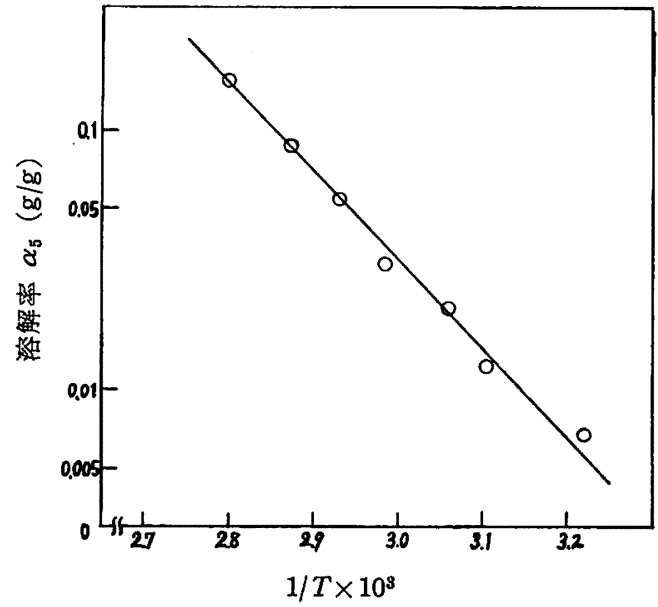

図 9 (a) $\mathrm{LAS}_{3}$ ガラスの $\log \alpha_{5}$ と $1 / T$ の関係

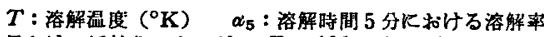
見かけの活性化エネルギー $E_{\mathrm{A}}=16 \mathrm{kcal} / \mathrm{mol}$

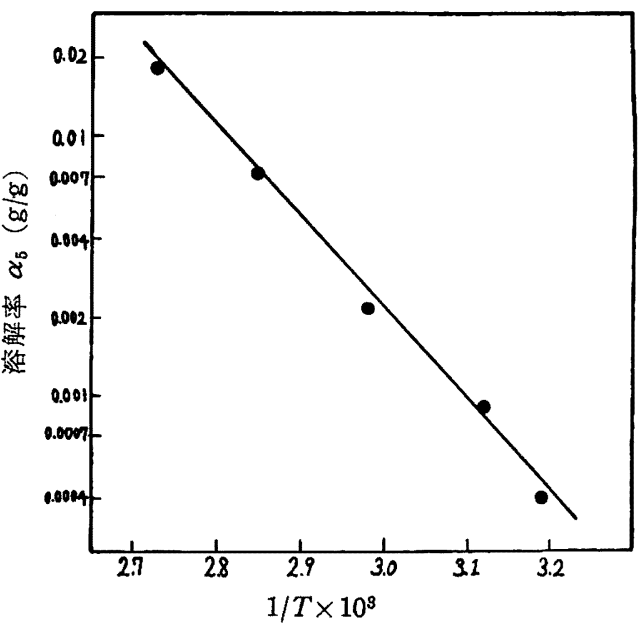

図 9 (b) $\mathrm{LAS}_{3}$ 結晶化試料の $\log \alpha_{5}$ と $1 / T$ との関係 $\alpha_{5}, T$ 红図 9 (a) $<$ 同七 
酸の濃度および温度を変化して溶解曲線を求めるため行なった。 溶解用フラスコは $500 \mathrm{ml}$ の丸底硬質がラスを用い, 硫酸の量は $250 \mathrm{~m} l$ とした。実験の途中で，各測定点ごとに新しい硫酸と取 換えて浱度の变化による影響をできるだけ少なくするように心掛 けた。

2・3・1 ガラスの溶解実験 $\mathrm{LAS}_{3}$ ガラス試料について, 濃度 $0.5 \mathrm{~N}$ の硫酸中への溶解量を各温度に扣いて測定した。その溶解 壮線を図 8 に示した。四からわかるように溶解量は温度とともに 增人する。いま溶解時間 5 分の場合の 溶解率 $\alpha_{5}$ の対数値と絶対温度の逆 数との関係を図に点経す れば，図9(a) に示すよ らになる。この場合の見 掓けの活性化エネルギー は, $16 \mathrm{kcal} / \mathrm{mol}$ となっ た。また溶解温度を一定 $\left(70^{\circ} \mathrm{C}\right)$ として硫酸の濃度 を, $0.5 \mathrm{~N}, 1 \mathrm{~N}, 2 \mathrm{~N}$, $4 \mathrm{~N}$ と変化した場合の溶 解兆線を図 10 に示した。 この場合溶解時間 20 分 の場合の溶解率 $\alpha_{20}$ と 顺酸の濃度との関係を各 渻度汇ついて示せば，四 11 のよ5になり，濃度 $2 \mathrm{~N}$ のところで浴解染 $\alpha_{20}$ が極大値を持つこと が示された。

次に MS 系ガラス試 料の溶解曲線の代表的な ものを図 12 に示した。 汹は濃度 $0.5 \mathrm{~N}$, 溶解温 度 $70^{\circ} \mathrm{C}$ の場合である。 また溶解時間 20 分のと きの溶解䊝 $\alpha_{20}$ と硫酸の

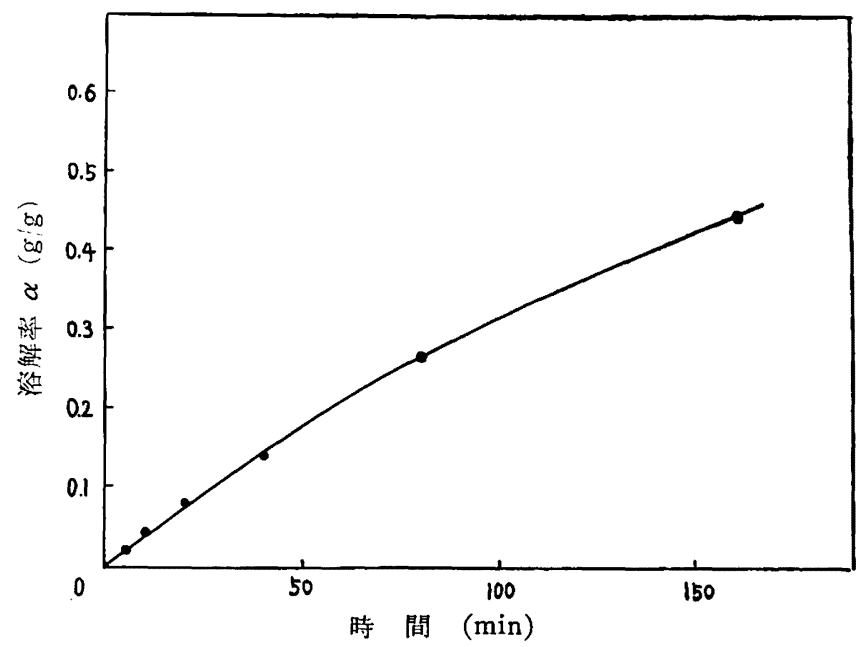

図 12 マイカースポシューメン系ガラス試料の溶解曲線 $\mathrm{H}_{2} \mathrm{SO}_{4}$ 㩐度 $0.5 \mathrm{~N}$ 浩解温度 $70^{\circ} \mathrm{C}$

目 11 温度変化に対する $\mathrm{LAS}_{3}$ ガラ ス陚料の $\log \alpha_{20}$ と $\log N$ との関係 $\alpha_{20}$ : 溶解時間 $20 \mathrm{~min}$ 溶解率

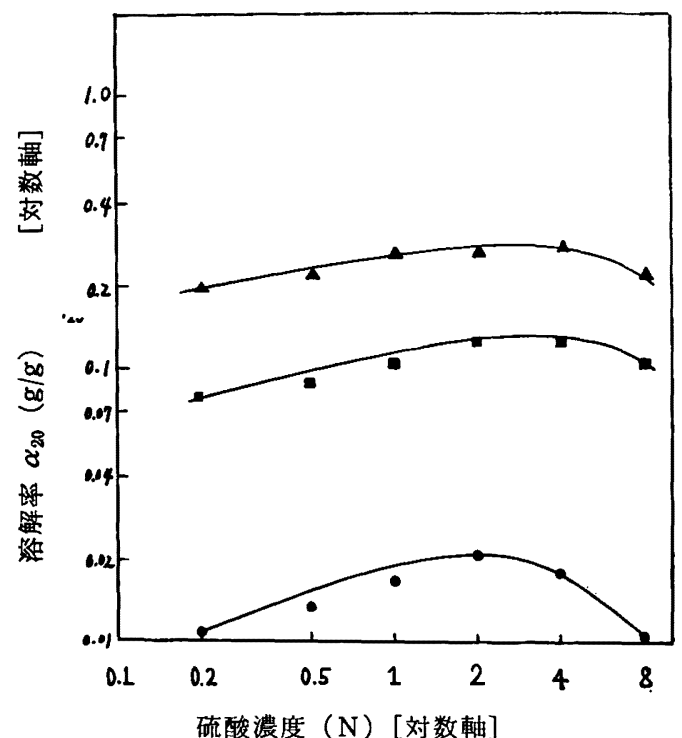

図 13 温度変化に対するマイカースポジューメン系 ガラス試料の $\log \alpha_{20}$ と $\log \mathrm{N}$ の関係

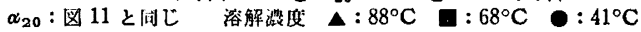

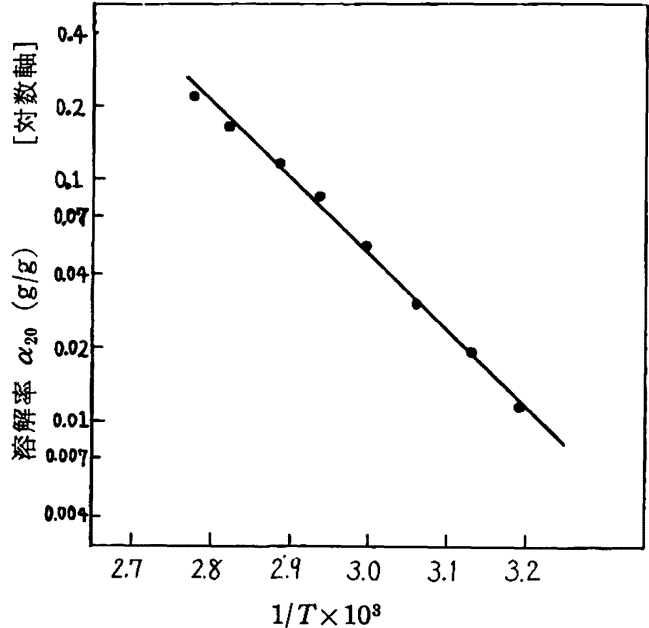

因 14 マイカースポジニメン系ガラス試料の $\log \alpha_{20}$ と $\log 1 / T$ との関倸

$T$ : 溶解温度 $\left({ }^{\circ} \mathrm{K}\right) \quad \alpha_{20}$ : 困 11 と间

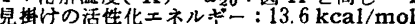

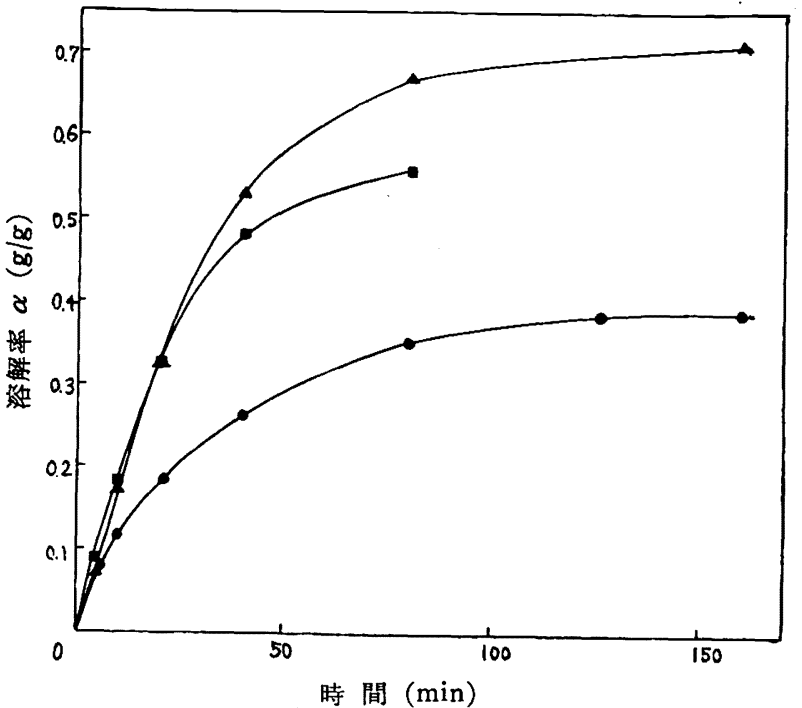

図 $15 \mathrm{LAS}_{3}$ 結晶化試料の溶解曲線

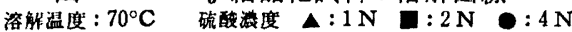


濃度との関係を示すと，図 13 のようになり，濃度 $2 \mathrm{~N}$ 付近に おいて極大を示すことがわかる。また溶解時間 20 分のとさの， $0.5 \mathrm{~N}$ 硫酸に対寸る溶解率 $\alpha_{20}$ の対数値と 絶対温度の逆数との

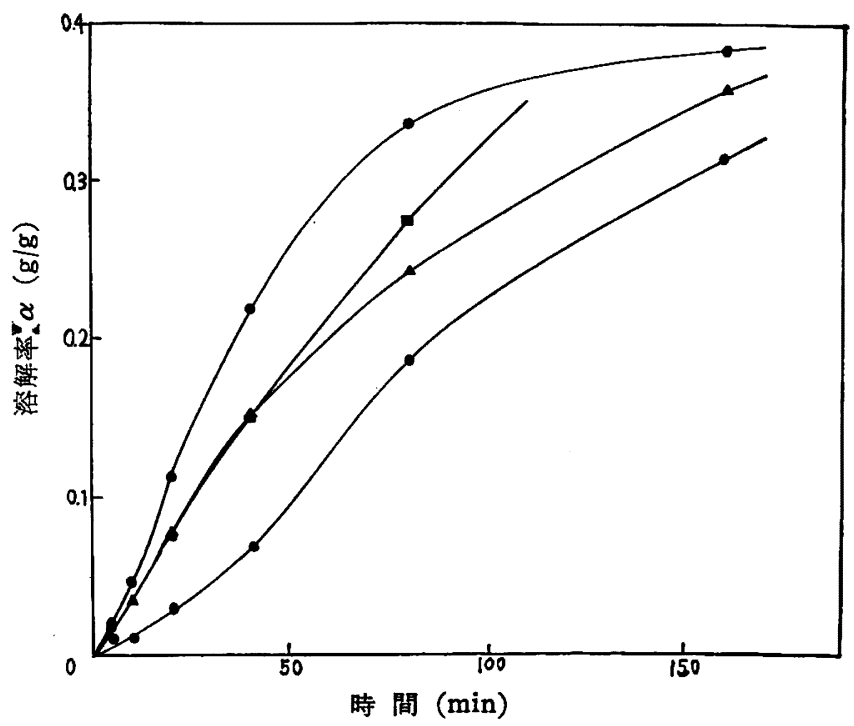

因 $16 \mathrm{LAS}_{3}$ 結晶化試料の溶解曲線

溶解温度: $70^{\circ} \mathrm{C}$ 硫酸温度 $\bullet: 0.5 \mathrm{~N}, \square: 0.1 \mathrm{~N}, \triangle: 0.25 \mathrm{~N}, \bullet: 0.05 \mathrm{~N}$

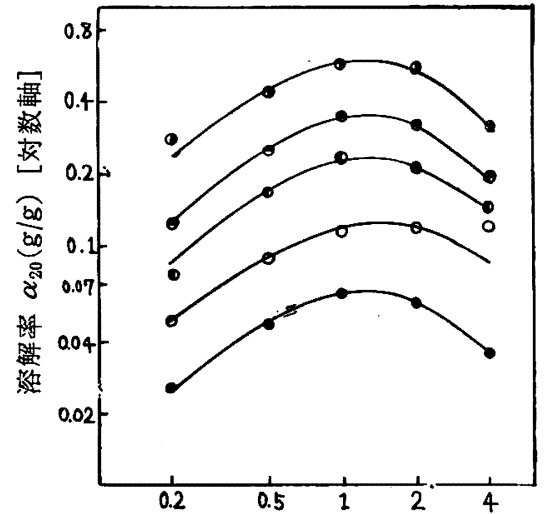

硫酸濃度（N) [対数軸]

図 17 温度変化に対する $\mathrm{LAS}_{3}$ 結晶化試料の $\log \alpha_{20}$ と $\log \mathrm{N}$ の関俰

溶解温度 $\odot: 82^{\circ} \mathrm{C} \odot: 70^{\circ} \mathrm{C} \quad 0: 62.5^{\circ} \mathrm{C} \quad \mathrm{O}: 55^{\circ} \mathrm{C} \quad 0: 47.3^{\circ} \mathrm{C}$

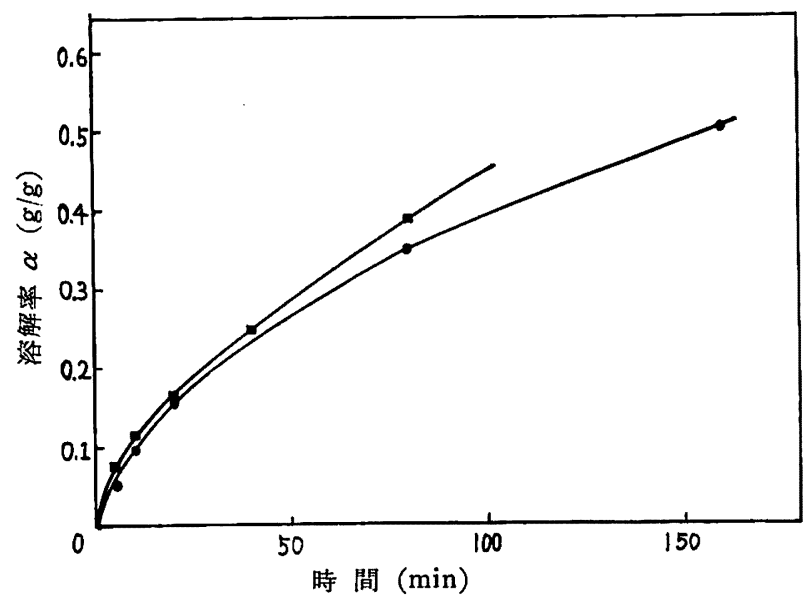

因 18 マイカースポシューメン系結晶化試料の溶解曲線 添解温度 : $70^{\circ} \mathrm{C}$ 硫酸浱度 $: 2 \mathrm{~N}, 9: 0.5 \mathrm{~N}$
関係を求めると，図 14 のようになり，この場合の見掛けの活性 化エネルギーを計算すると $13.6 \mathrm{kcal} / \mathrm{mol}$ となった。

$2 \cdot 3 \cdot 2$ 結晶化試料の溶解実験 $\mathrm{LAS}_{3}$ 試料の結晶化物につい て, 一定温度 $\left(70^{\circ} \mathrm{C}\right)$ 飞打ける溶解曲線を硫酸の各濃度ごと求 めた結果を図 15 拈よび図 16 に示した。図 15 は硫酸濃度 $1 \mathrm{~N}$ 以上の場合の溶解曲線であるが，この場合の曲線は単調增加曲線 であるが，図 16 は濃度が $1 \mathrm{~N}$ 以下の低い場合であるが，曲線 はS字形を示していることがわかる。また溶解時間 20 分の場合 の溶解率 $\alpha_{20}$ と硫酸の濃度との関係を各温度について求める と、図 17 に示すよ5になる。

この場合濃度 $1 \mathrm{~N}$ を境にして溶解率 $\alpha_{20}$ の極大値を示すこと がわかる。

次に MS 系結晶化試料について，溶解温度 $70^{\circ} \mathrm{C}$ に打ける溶 解曲線を, 図 18 に示す。また，溶解時間 20 分の場合の溶解摔 $\alpha_{20}$ と硫酸の濃度との関係を求めると, 図 19 に示すようになる。 因に見られるように，低い温度 $45^{\circ} \mathrm{C}$ の場合には，濃度 $2 \sim 3 \mathrm{~N}$ 付近に極大值を示すように思われるが， $88^{\circ} \mathrm{C}$ の場合に拈いては， ほとんど極大值は見られない。次に溶解時間 20 分における溶解 率 $\alpha_{20}$ の対数值と溶解温度の絶対温度の逆数との関係を示すと, 因 20 のようになり，約 $60^{\circ} \mathrm{C}$ 付近でこの直線が屈折することを

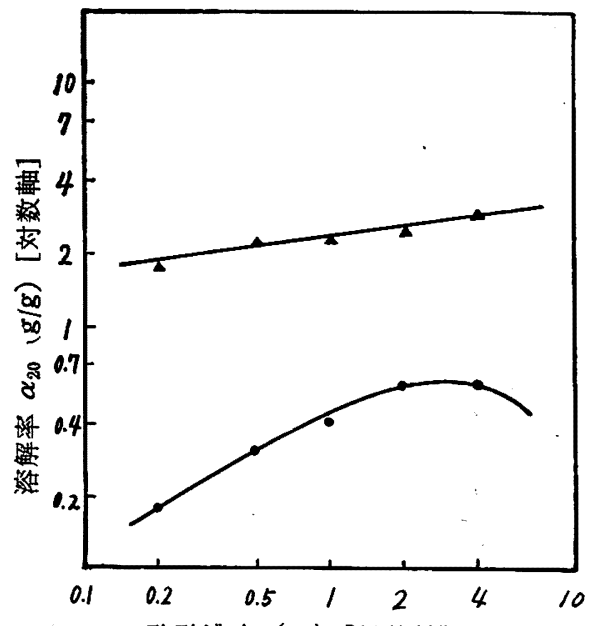

硫酸濃度 $(\mathrm{N})$ [対数軸]

因 19 温度変化に対するマイカースポジューメン 結晶化試料の $\log \alpha_{20}$ と $\log N$ の関係 㳊解温度 $\Delta: 88^{\circ} \mathrm{C} \bullet: 45^{\circ} \mathrm{C}$ $\alpha_{20}$ : 図 11 と同じ

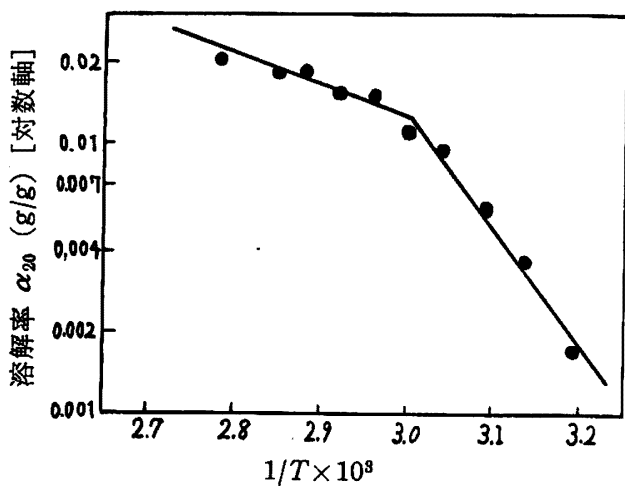

因20 マイカースポシューメン系結晶化ガラス 試料の $\log \alpha_{20}$ と $1 / T$ との関係 $T$ : 溶解温度 $\left({ }^{\circ} \mathrm{K}\right) \quad \mathrm{H}_{2} \mathrm{SO}_{4}$ 渷度 $0.5 \mathrm{~N}$ $\alpha_{20}:$ 図 11 と周! 
示した。また見掛けの活性化エネルギーは温度の高い範囲におい ては， $11.5 \mathrm{kcal} / \mathrm{mol}$ ，低い温度範囲に打いては， $39.5 \mathrm{kcal} / \mathrm{mol}$ のような大きな値を示した。

\section{3 実験結果に対する考察}

\section{3・1 フッ化水素酸に対するガラスの溶解実験に対する考察}

一般のガラスはケイ酸分が多く，65～80\% の $\mathrm{SiO}_{2}$ が含有し ている。このよ5なガラスのフッ化水素酸に対する溶解現象は， ます $\mathrm{SiO}_{2}$ 成分と $\mathrm{HF}$ との反応によってガラスが浸食され，そ の反応生成物が試料の表面に沈着して反応抵抗層を形成するるの と考えられる。したがってその場合の反応速度は抵抗層の生成と ともに低下するためその溶解曲線は，図21（a）上5な様相を示 すことになる※1。すなわち抵抗層が時間ととすにその厚さを增 し，ある時間以上フッ化水素酸に浸漬しても溶解滔はそれほど進 まず，溶解速度はほとんど零に近つくようになる。この場合もし 溶解時間 1 分の後, すなわちそのときの溶解率が $\alpha_{1}$ に達したと する。そのとき試料表面に形成された抵抗層を水で洗浄して除去 したのち，再び第 2 回目の溶解実験を行なえば溶解曲線は，図

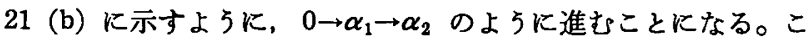
こでさらに洗浄を行ない, 再び第 3 回目の溶解操作を行なえば, 溶解曲線は， $\alpha_{2} \rightarrow \alpha_{3}$ のよ5に進むことになる。このよ5な実験 を繰返して測定点 $\alpha_{1}, \alpha_{2}, \alpha_{3}, \cdots$ を求めて点経すれば， $S_{1}$ 曲線 が得られる。次に洗浄間隔（1 回の溶解規定時間）を 3 分とし $\tau$ ，この実験を繰返し，その測定点を求めれば， $\alpha_{3}, \alpha_{6}, \cdots$ が得 られ、これらを結べば $\mathrm{S}_{3}$ 曲線が得られる。

この結果からわかることは，洗浄間隔を大きくとり溶解些験を
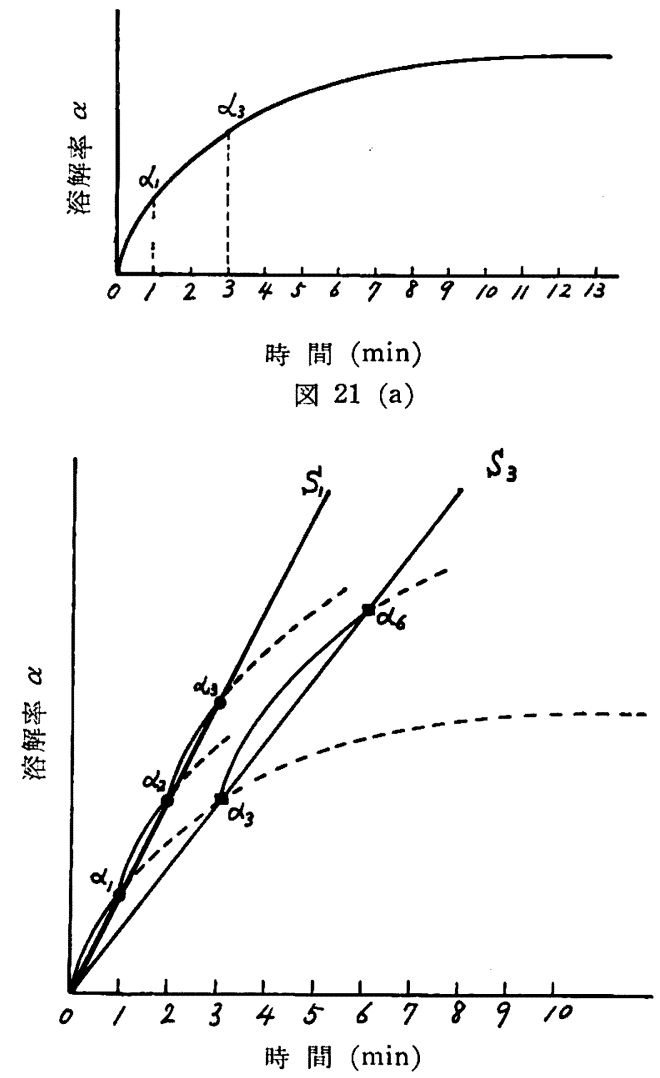

因 21 (b)
行なえば, 溶解率曲線は洗浄間隔の小さいものに比べて低く出る はずである。このこと多くのガラスに対して実証されている。と ころが本実験の図 4 に示された結果は，これと逆である。この理 由についての説明は今のところ簡単ではない。本実験で取扱った 特殊な組成のガラスに対して，フッ化水素酸の浸食作用がどのよ らな機構で行なわれるか，また洗浄液がどのように抵抗層に作用 するか詳細な研究が必要であるが，ここに実験事実だけを取あえ ず示した次第である。

次に MS 系結晶化試料の溶解作用に特に認められた事実に試 料表面から微紐な剥離片が生成することである。この䟝離片を集 めてX線分析を行なったところ，マイカの結晶であった。MS 系 結晶化試料は主として，マイカおよび きていることは前述の通りであるが，このことから試料の溶解現 象は，ます溶解速度の大きな $\beta$ ースポジューメンが先に溶解し， 溶解し難いマイカが陚料中に取り残され，溶解作用がある程度進 行してからマイカだけが䟝離片となって陚料表面から離脱するも のと考えられる。一般に溶解中このような䟝離現象を示すような 場合の溶解曲線はS 字形曲線を示するのと考えられる $\% 2 。$

\section{2 硫酸に対する溶解式に咸する考察}

$\mathrm{LAS}_{3}$ ガラス試料の溶解曲線を示す図 8 の結果を, $\log \alpha$ と $\log t$ との関係で表わすと，図 22 のようになる。溶解時間の初 期においてこの関係がほぼ直線で示されることから，溶解率 $\alpha$ と溶解時間 $t$ との関係は,

$$
\alpha^{n}=k t, \quad n \fallingdotseq 0.985
$$

で示され， $n$ はほほ 1 に近い値をとる。

次に $\mathrm{LAS}_{3}$ 結晶化試料住対する $\log \alpha$ と $\log t$ との関係を示 すと, 図 23 の上5になる。これは硫酸の濃度が $0.5 \mathrm{~N}$ の場合 である。因からわかるよ5に時䦘の初めに抋いてこの間係は直線 性を示す。したがってこの場合もその溶解式は（1）式で表わす ことができ， $n \doteqdot 0.91$ の值をとる。

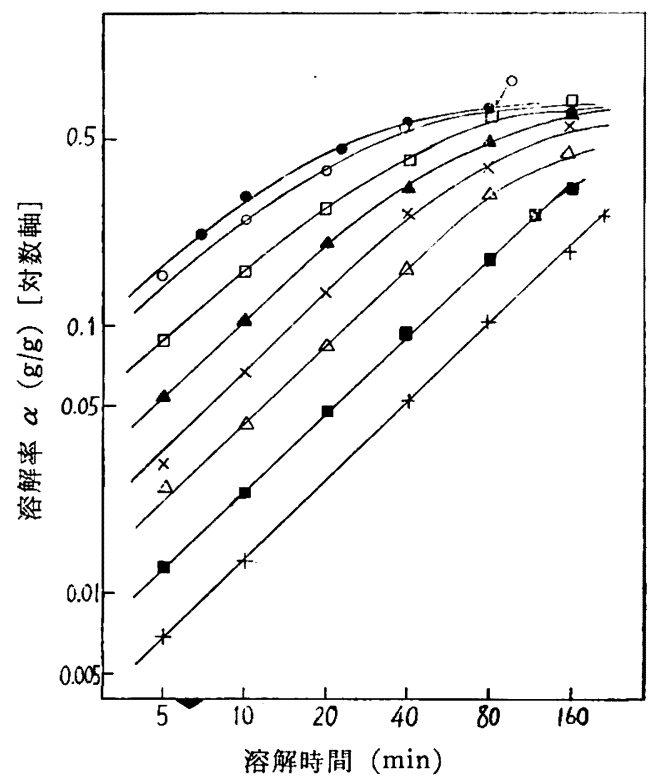

図 22 溶解温度の变化に対する $\mathrm{LAS}_{2}$ ガラス 試料の $\log \alpha$ と $\log t$ 曲線 $\mathrm{H}_{2} \mathrm{SO}_{4}$ 浩度 $0.5 \mathrm{~N}$

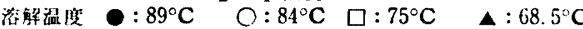
$\times: 62.5^{\circ} \mathrm{C} \triangle: 55^{\circ} \mathrm{C}: 47.7^{\circ} \mathrm{C}+: 40.2^{\circ} \mathrm{C}$

※2 潼沢, 境野, 森谷, 東工大英文報告に投稿中,

$※ 1$ 長谷川溙実験。 


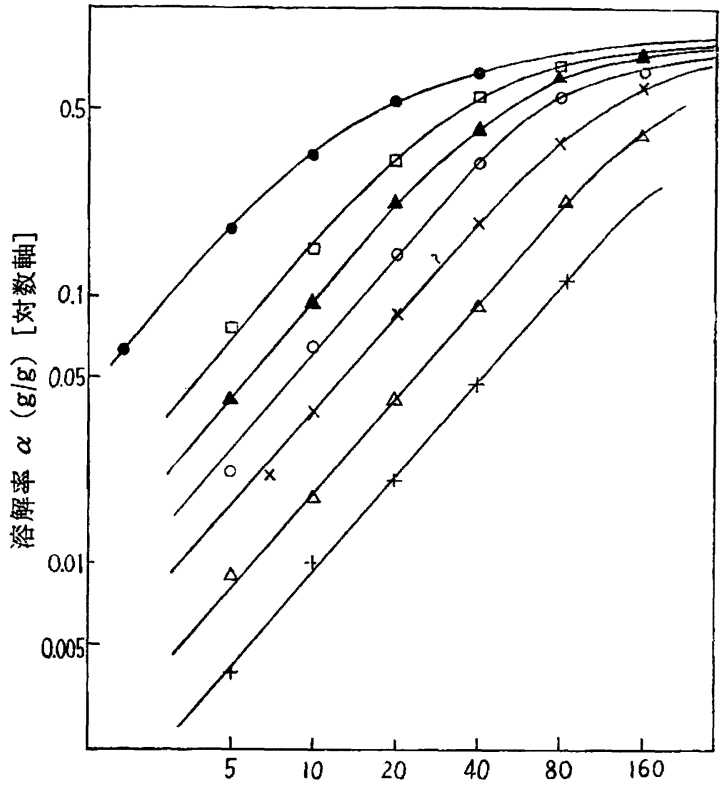

溶解時間 ( $\mathrm{min}$ ) [対数軸]

図 23 溶解温度の変化に対する $\mathrm{LAS}_{3}$ 結晶化 試料の $\log \alpha$ と $\log t$ 曲線 $\mathrm{H}_{2} \mathrm{SO}_{4}$ 港度 $0.5 \mathrm{~N}$

膟解温度 $\quad: 92^{\circ} \mathrm{C} \quad \square: 77^{\circ} \mathrm{C} \quad \Delta: 70^{\circ} \mathrm{C} \quad \mathrm{O}: 62.8^{\circ} \mathrm{C}$ $x: 54.5^{\circ} \mathrm{C} \quad \triangle: 48^{\circ} \mathrm{C}+: 40^{\circ} \mathrm{C}$

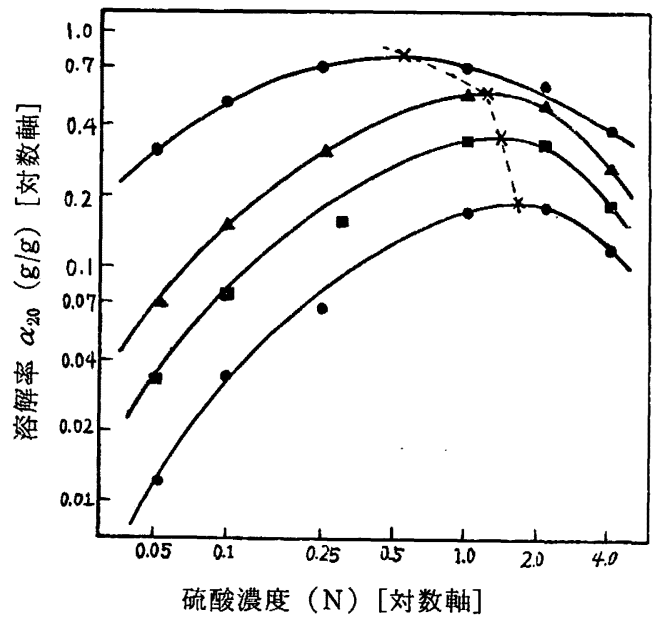

因 $24 \mathrm{LAS}_{3}$ 結晶化試料の $\log \alpha$ と $\log \mathrm{N}$ の関係 浴解温度 $70^{\circ} \mathrm{C}$

搖解時間 $\mathrm{O}: 160 \mathrm{~min} \triangle: 40 \mathrm{~min} \square: 20 \mathrm{~min} \bullet: 10 \mathrm{~min}$ $\cdots \times \cdots \times \cdots$ 最大点

次に溶解温度 $70^{\circ} \mathrm{C}$ の場合，各溶解時間について, 溶解率 $\alpha$ と硫酸濃度 $\mathrm{N}$ との関係を対数值で表わすと，図 24 のよ5になる。 各溶解時間ともに溶解率の極大值が表われるが，その位置は溶解 時間の長くなるにつれて濃度の低い方に移動する。

次に MS 系ガラス試料の溶解率 $\alpha$ と溶解洔間との対数值を 点緅すれば，図 25 に示すような值線関係が示され，溶解式は （1）によって表わされることがわかる。この場合 $n \div 1.11$ とな る。

また MS 系結晶化試料について子同様に, $\log \alpha$ と $\log t$ との 関係は，図 26 のよ5に示され，その溶解式は（1）式で表わさ れることがわかる。たたし $n \fallingdotseq 2$ となる。

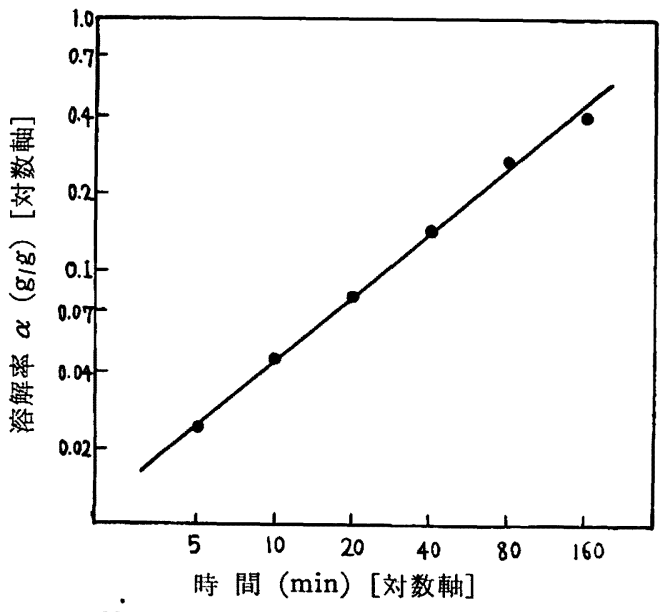

図 25 マイカースポシューメン系ガラス試料 の $\log \alpha$ と $\log t$ の関係

$t:$ 浴解将间 $\mathrm{H}_{2} \mathrm{SO}_{4}$ 婊度: $0.5 \mathrm{~N}$ 溶解温度 $: 70^{\circ} \mathrm{C}$

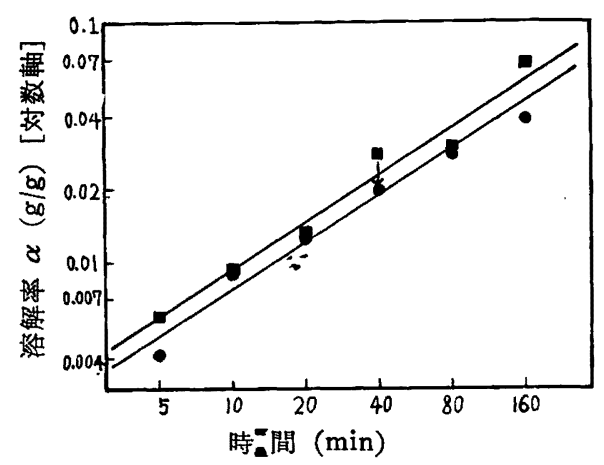

図 26 マイカースポジューメン系結晶化試料 の $\log \alpha$ と $\log t$ との関係 $t:$ 溶解恃間 溶解温度 $: 70^{\circ} \mathrm{C}$ 硫酸溚度 $1: 2 \mathrm{~N}, \bullet: 0.5 \mathrm{~N}$

\section{4 総括}

(1) $\mathrm{Li}_{2} \mathrm{O} \cdot \mathrm{Al}_{2} \mathrm{O}_{3} \cdot 3 \mathrm{SiO}_{2}$ ガラスおよびマイカ・スポジューメ ン系ガラスについて，それらのガラス状態ならびに結晶状態に括 けるフッ化水素酸扣よび硫酸に対する溶解現象について研究した。

2）上記 2 種のガラス粉末のフッ化水素酸に対する溶解におい て，溶解作用とともに試料表面に反応生成物が沈着することが認 められ，この生成物が溶解速度に影響を与えることが示された。

3）マイカ・スポジューメン系の結晶化試料のフッ化水素酸に 対する溶解曲線は時間の初めはゆるやかに上昇するが, 時間が経 過するにつれて次第に急上昇を示し，一定の直線性を示す。また 溶解中に䟝離片が試料表面から離脱することが認められた。この 微紐な䟝離片はX線分析の結果マイカの結晶であることが確認さ れ，この種の結晶化物の溶解現象はまずフッ化水素酸に溶解し易 いßースポジューメン結晶が選択的に溶解し去り，溶け難いマイ カはそのまま試料から䐣離することが確かめられた。

4) $\mathrm{Li}_{2} \mathrm{O} \cdot \mathrm{Al}_{2} \mathrm{O}_{3} \cdot 3 \mathrm{SiO}_{2}$ ガラスの硫酸に対する溶解曲線は溶解 時間の初めに打いては直線的に示され, 後次第に溶解速度が減少 するように示された。またその溶解率は硫酸の濃度によって異な り，濃度が $2 \mathrm{~N}$ 付近のところで極大值をもつことが認められた。

5) $\mathrm{Li}_{2} \mathrm{O} \cdot \mathrm{Al} \cdot 3 \mathrm{SiO}_{2}$ 結晶化試料の硫酸に対する溶解曲線は硫 酸の濃度の低い場合は， $\mathrm{S}$ 字形を示すが，1N 以上の濃度の場合 は単調增加曲線を示す。また濃度 $1 \mathrm{~N}$ 付近のところで溶解率が 
極大を示すことが認められた。

6) マイカ・スポジューメン系ガラスの硫酸に対する溶解率は

硫酸の濃度が $2 \mathrm{~N}$ 付近のところで極大值を示した。

7）硫酸に対する溶解率 $\alpha$ と溶解時間 $t$ との関係は $\alpha^{n}=k t$
なる式で示される。ただし $n$ の值は，マイカ・スポジューメン 系結晶化試料の場合には， $n \doteqdot 2$ の值を示したが，その他の場合 は,いずれも $n \div 1$ の値を示した。

終りに当り，実験担当に御協力下さった下平高次郎氏に厚く感 謝する次第である。

\title{
肥料塩-クエン酸含有液系における肥料塩の溶解性
}

(昭和 37 年 12 月 8 日 受理)

\author{
金沢孝 文* ・伊藤 力生**
}

\begin{abstract}
ク溶性肥料塩のクェン酸含有液への溶解現象の研究の一部として, 石灰塩, 苦土塩, リン酸塩, ケイ酸塭等の非水溶性 肥料成分含有塩につき, クエン酸液, クエン酸塩液にたいするそれらの溶解性をしらべた。試料の種類, 溶剤の種類・濃

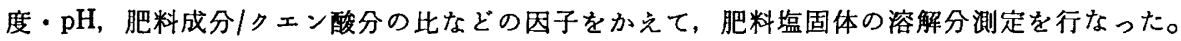

その結果，（1）溶剤種類による溶解力の差異を，おなじ試料量/クェン酸比でくらべると，原則として，2\%クェン 酸 $>10 \%$ 中性クエン酸フンモニウム>10\% 中性クエン酸ナトリウムとなること, (2) 試料量/クエン酸比または液量 を同一にして，中性クェン酸塩液のクェン酸分濃度をたかめると，溶解率もそれに応して大となること（3）溶剂の $\mathrm{pH}$ が增加するほど溶解率は低下すること，などの傾向を数值的にあきらかにすることがきた。また試料の種類による 溶解性のちがいの原因, 各溶剤の溶解作用機構のちがいなどに関して考察した。
\end{abstract}

\section{1 藉言}

肥料塩のクエン酸溶解機構検討の一端として,さきに著者の 1 $人^{1,2)}$ は, 溶成苦土リン肥のそれをあつかった序諭的記述を提出 した。さらに本問題を基礎的にしらべるため, 試料に, 非水溶性 肥料塩として考えられる各種純薬, すなわち石灰塩, 苦土塩, リ ン酸塩, ケイ酸塩などを用い，また溶剤も，クエン酸だけでなく 中性その他に $\mathrm{pH}$ をかえたクェン酸アンモニウム, クェン酸ナト リウム溶液を採用することにより，ひろく肥料塩-クエン酸含有 液系の物理化学的諸性質をみた。本報はそれらの結果のうち，ク エン酸含有液にたいする肥料塩の溶解性に関する部分の一部で, 本娭討によりいままで不明またはあいまいであった多くの事項が かなり明確化するようになった。

\section{2 実験}

\section{$2 \cdot 1$ 試 料}

$\mathrm{Ca}, \mathrm{Mg}, \mathrm{P}, \mathrm{Si}$ 中の 1 種または 2 種を扔のおのふくむ非水溶 性純薬, およびそれらの応用としての溶成苦土リン肥（4成分を 含有）を用いた。種類と調製法を以下に示す。

（i）水酸化石灰：合成による3)。（ii）水酸化苦土：合成に よる4)。(iii) リン酸二石灰: 1 級試薬を $100^{\circ} \mathrm{C}$ に乾燥し, 無水 物にして用いた。（iv）リン酸二苦土：1 級試薬を $100^{\circ} \mathrm{C}$ に乾 燥し本和物 $\left(\mathrm{MgHPO}_{4} \cdot 3 \mathrm{H}_{2} \mathrm{O}\right)$ のままで用いた。（v） ケイ酸石

* 東京都立大学工学部工業化学教室: 東京都世田谷区深沢町.

** 現勤務先：東京電力株式会社.

1）金沢，工化 $63 ， 569$ (1960).

2）金沢, “溶成苦土リン肥に関する研究” 熔成橉肥協会(1961) p. 135 , p. 142.

3）日化会, “実験化学講座 9 , 無機化合物の合成と精彆” 丸 善 (1958) p. 165.

4）日化会, “実駼化学講座 9, 無機化合物の合成と精製” 丸 善 (1958) p. 145.
灰: 市販試薬, 分析値 $\mathrm{SiO}_{2} 71.18, \mathrm{CaO} 19.95, \mathrm{H}_{2} \mathrm{O}$ 残部 (各 \%)，ほとんど非晶質のもの。（vi）溶成（苦土）リン肥：市販 製品，分析值 $\mathrm{SiO}_{2} 25.25, \mathrm{CaO} 31.95, \mathrm{MgO} 16.85, \mathrm{~T}-\mathrm{P}_{2} \mathrm{O}_{5}$ 21.20 (各\%)，リン酸ク溶率 $98.0 \% ， 180$ インチメッシュ全通。 リン酸二石灰，リン酸二苦土兩試薬は，ものによってはク土ン 酸液に溶けにくいのもあるので，2\%クェン酸液になるべく溶恀 やすいものをえらんだ。（vi）以外はメノウ乳鉢で微粉にして供 試した。リン酸二苦土中の結晶水については，配合計算上補正を して，実験結果中にはつねに無水物としてあらわしてある。

溶剤は，2\%クエン酸，10\%中性クエン酸アンモニウム，10\% 中性クエン酸ナトリウムを扣むに用いた。あとの 2 者は, クェン 酸夜をアンモニア水，カセイソーダでそれぞれ中和し， $\mathrm{pH}=7$ に したもので,\%は溶液中のクェン酸分に関しての\%を意味する。 他に濃度，pH をかえたものも使用した。クエン酸液の調製は特 級クエン酸を使い, 濃度は比重とカセイソーダ滴定とでさだめた。 $2 \cdot 2$ 測 定

$30^{\circ} \mathrm{C}$ 定温水槽中で，スターラーかきまぜによって，固体試料 を溶剂と作用させた。試料/溶剤のわりあいは，クエン酸を $\mathrm{H}_{3} \mathrm{Ci}$ とかくと, $\mathrm{Ca} / \mathrm{Ci}, \mathrm{Mg} / \mathrm{Ci}$ などのモル比 (R/Ci) を尺度にして変 化させた。抽出時間はとくにことわりのないものは 30 分とする。 終了後グラスフィルターで迅速にロ過し, 不溶分量から溶解率を 判定した。また所定の肥料塩一溶剤系における完全溶解領域をあ きらかにした。この溶解可能つ範囲は，抽出夜の物理化学的性 質 ${ }^{5)}$ を測定するばあい，供試液調製上必要となる資料でもある。

\section{3 結 果と考察}

$3.12 \%$ クエン酸, $10 \%$ クエン酸アンモニウム, $10 \%$ クエ ン酸ナトリウム使用による溶解率測定

試料 6 種につき，それぞれ $\mathrm{R} / \mathrm{Ci}$ をかえて，溶解実験を行なる

5）金沢，伊滕，末發表. 